\title{
Automobile in the Disposition of Energy-saving Houses
}

\author{
CHYBíK Josef ${ }^{1, a^{*}}$ \\ ${ }^{1}$ Faculty of Architecture BTU Brno, Poříčí 5, 63900 Brno, Czech Republic \\ achybik@fa.vutbr.cz
}

Keywords: Automobile, garage, architecture, house disposition, thermal protection, linear heat transfer coefficient, thermal transmission coefficient.

\begin{abstract}
In the disposition of energetically economic houses, automobile abandons its stereotype held for so many years according to which it was placed to rest "under one roof" with other residential and utility rooms. However, this diagram shows a range of collisions manifesting with difficult building details, with occurrence of thermal bridges and thermal relations. This results in increased financial demands for drafting efficient thermal-insulation layers or higher demand for energy consumption necessary to heat up the building. Generally, architects and structural engineers are not sufficiently aware of the fact that at the same time this is a factor that provides higher potential for faster ageing of car bodies and chassis when cars are parked "inside the house" than in means of transport parked in open carports or in an open space.
\end{abstract}

\section{Introduction}

The topic of garages has been thoroughly covered by Štikar [7] and garage ventilation by Drkal [3] and [4]. This Paper focuses on garages without heat sources situated in family houses or residential buildings. They are unheated spaces.

\section{Unheated Spaces According to the Czech Norm CSN 730540}

Unheated buildings or unheated zones in buildings are covered by CSN 730540 Thermal protection of buildings - Part 2: Requirements. [1] The norm defines required and recommended heat transfer coefficient values for buildings with prevailing project temperature within the interval of $\theta_{\text {im }}=18^{\circ} \mathrm{C}$ to $22^{\circ} \mathrm{C}$, Table 1 .

Table 1 Required and recommended heat transfer coefficient values for buildings with prevailing project temperature $\theta_{\text {im }}$ within the interval $18^{\circ} \mathrm{C}$ to $22^{\circ} \mathrm{C}$, incl. [1]

\begin{tabular}{|l|l|l|l|}
\hline \multirow{2}{*}{ Construction description } & \multicolumn{2}{|l|}{$\begin{array}{l}\text { Thermal transmission coefficient } \mathrm{U} \\
{\left[\mathrm{W} /\left(\mathrm{m}^{2} \cdot \mathrm{K}\right)\right]}\end{array}$} \\
\cline { 2 - 4 } & Required values & $\begin{array}{l}\text { Recommended } \\
\text { values }\end{array}$ & $\begin{array}{l}\text { Recommended } \\
\text { values for passive } \\
\text { buildings } \\
\mathrm{U}_{\text {pas, } 20}\end{array}$ \\
\hline $\begin{array}{l}\text { Ceiling under unheated attic with } \\
\text { roof with no thermal insulation }\end{array}$ & 0.30 & $\mathrm{U}_{\mathrm{rec}, 20}, 20$ & 0.10 to 0.15 \\
\hline $\begin{array}{l}\text { Ceiling and inside wall of heated to } \\
\text { unheated area }\end{array}$ & 0.60 & 0.20 & 0.20 to 0.30 \\
\hline
\end{tabular}

The norm CSN 730540 also states that horizontal structures with a floor function above the outside environment and above unheated spaces such as garages must meet requirements concerning the heat transfer coefficient in Table 1 and requirements of floor structure contact temperature decrease. Thermal insulation layers are usually placed favourably on the cooler side. The norm also states that interior walls separating heated and unheated spaces, e.g. garages, must meet 
requirements concerning the heat transfer coefficient. Efficient thermal insulation is usually placed on the side of the unheated space.

The norm CSN 0540 also includes required and recommended values of linear and point heat transfer coefficient of thermal relations between the structures, Table 2.

Table 2 Required and recommended values of linear and point heat transfer coefficient of thermal relations between the structures [1]

\begin{tabular}{|l|l|l|l|}
\hline \multirow{2}{*}{ Type of linear thermal relation } & \multicolumn{2}{|l|}{$\begin{array}{l}\text { Linear heat transfer coefficient } \\
{[\mathrm{W} /(\mathrm{m} \cdot \mathrm{K})]}\end{array}$} \\
\cline { 2 - 4 } & $\begin{array}{l}\text { Required } \\
\text { values }\end{array}$ & $\begin{array}{l}\text { Recommended } \\
\text { values }\end{array}$ & $\begin{array}{l}\text { Recommended } \\
\text { values for } \\
\text { passive } \\
\text { buildings } \\
\psi_{\text {pas }}\end{array}$ \\
\hline $\begin{array}{l}\text { Outer wall continuing onto another structure, } \\
\text { e.g. a ceiling above unheated space }\end{array}$ & 0.20 & 0.10 & 0.05 \\
\hline
\end{tabular}

This shows that CSN 730540 concerns issues of the unheated garage space location in relation to heated space of the house as well. At the same time, the norm provides tools for solving them.
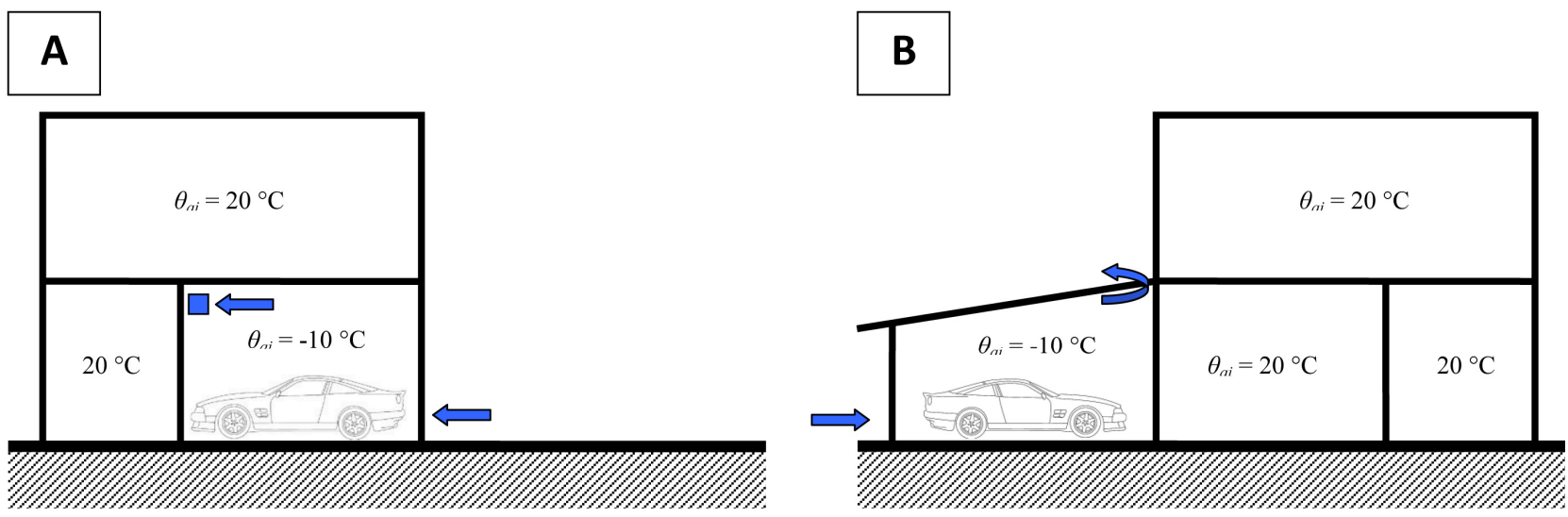

\section{C}
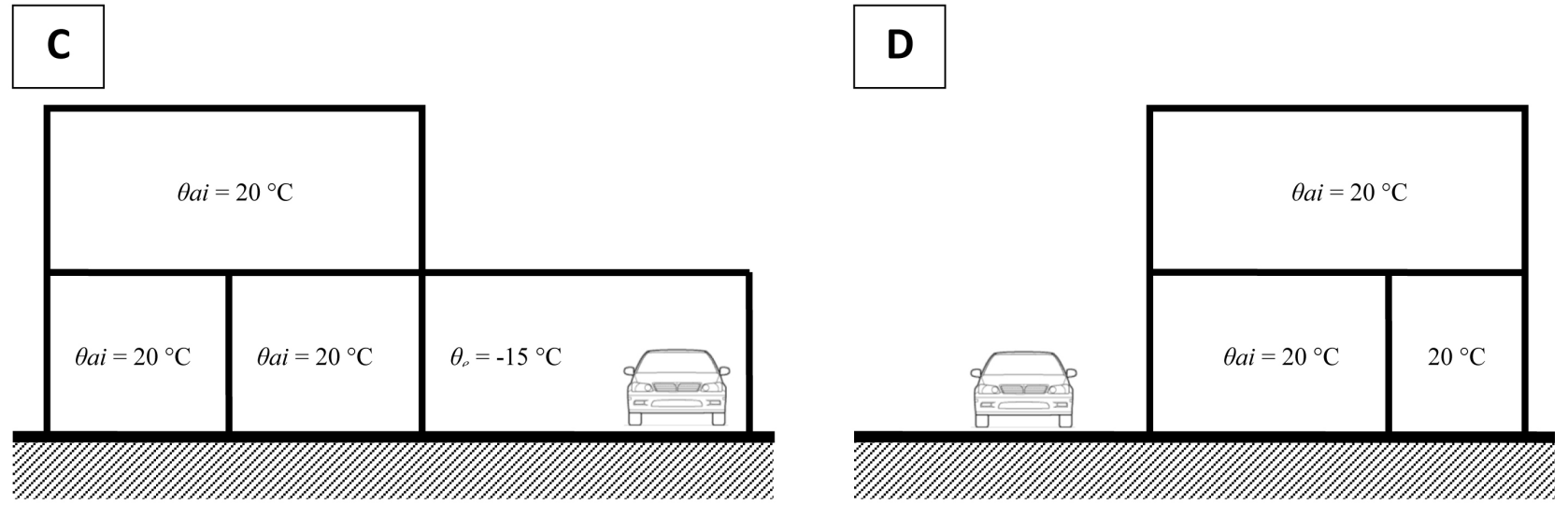

Fig. 1, A diagram of garage parking in a family house and garage ventilation

A - Garage is part of the house disposition, $\mathrm{B}$ - garage is before the house ground plan, $\mathrm{C}-$ the garage parking is under a carport, $\mathrm{D}-$ vehicles are parked in open space 


\section{Garage as an Unheated Space}

Why is it necessary to view garage as an unheated space? We know that an automobile needs fuel to run its compression-ignition engine or spark-ignition engine. Burning fuel produces exhaust fumes. Their amount is reduced to a minimum by means of a catalytic converter. Nevertheless, situations may occur when the garage environment can become contaminated in an enclosed space and without the necessary fresh air inlet. The main hazardous substances in automobile exhaust fumes are gases $\mathrm{CO}, \mathrm{NO}_{\mathrm{x}}, \mathrm{SO}_{2}$, cyclic hydrocarbons, aldehydes, unburned hydrocarbons and lead. Substances such as pyrene derivatives or soot have carcinogenic effects. [2] Continuous air flow prevents occurrence of harmful or dangerous concentration of gases or transport of exhaust gases into other parts of the building. The entire free space of ventilation apertures is defined in CSN 73 6058. [2] The ventilation aperture size required for one parking spot in garages for personal vehicles or vans and two-wheel vehicles is minimum $0.025 \mathrm{~m}^{2}$. In garages for trucks and special cars, buses, tractors and self-propelled machinery, the required aperture size is $0.045 \mathrm{~m}^{2}$.

With permanent air flow with no adjustments, temperature may drop to the level near outside temperature. This results in significant cooling of building structures on the surface as well as in their core. Fig. 1 shows diagrams with examples of garage placement.

In diagram A, garage is part of the house disposition. Due to ventilation, the air temperature is on the level near outside temperature. This results in increased heat flows. That is why it is necessary to put thermal insulation on interior walls and ceiling of the garage. If the outer walls do not get insulated, a linear thermal relation will occur. In case of inefficient ventilation, this manner of garage parking may cause water vapour condensation on cool parts of the car body or chassis.

Example " $\mathrm{B}$ " is more appropriate. Again, it is necessary to insulate the enclosure house wall. Increased attention should be paid to the contact of the wall with the house roof.

Example "C" presents a garage created as an open carport. This concept of a garage is very frequent. In case of point mounting of roof elements to the wall, it is necessary to eliminate point thermal bridges. [5]

Example "D" represents open parking, i.e. garaging with no way of protecting the automobile against weather conditions.

\section{Calculation Assessment}

Assessment of the thermal condition of the garage is shown on three examples. The assessment used a calculation program AREA [6] which assesses thermal situations using the two-dimensional thermal field method. We show the detail of the contact of a ceiling structure with a vertical wall for example. The calculation has been carried out in marginal conditions with the following interior air parameters: $\theta \mathrm{ai}=21^{\circ} \mathrm{C}$, , $\mathrm{ai}=50 \%$ and outer environment parameters: $\theta \mathrm{e}=-10{ }^{\circ} \mathrm{C}$, resp. $\theta \mathrm{e}=-15$ ${ }^{\circ} \mathrm{C}$ a $\varphi \mathrm{e}=84 \%$.

Table 3 Materials used for structure modelling

\begin{tabular}{|l|l|l|l|l|l|}
\hline No. & Name & $\begin{array}{l}\text { Heat transfer } \\
\text { coefficient } \\
\lambda\end{array}$ & $\begin{array}{l}\text { Specific } \\
\text { thermal } \\
\text { capacity } \\
\mathrm{c} /(\mathrm{m} \cdot \mathrm{K})]\end{array}$ & $\begin{array}{l}\text { Volume } \\
\text { weight } \\
{[\mathrm{J} / \mathrm{kg} \cdot \mathrm{K}]}\end{array}$ & $\begin{array}{l}\text { Diffusion } \\
\text { resistance } \\
\text { factor } \\
{\left[\mathrm{kg} / \mathrm{m}^{3}\right]}\end{array}$ \\
\hline 1 & Brickwork & 0.088 & 1000 & 650 & 10 \\
\hline 2 & Reinforced concrete & 1.740 & 1020 & 2500 & 32 \\
\hline 3 & EPS - polystyrol & 0.035 & 1270 & 25 & 50 \\
\hline 4 & Full burnt bricks & 0.860 & 900 & 1800 & 9 \\
\hline 5 & Sound insulation in the floor & 0.038 & 800 & 40 & 1 \\
\hline 6 & Simple concrete & 1.230 & 1020 & 2100 & 17 \\
\hline
\end{tabular}


The structure composition is shown in Table 3. Numbers were assigned to individual materials with applicable characteristics; these numbers are used in the description of details concerned, Fig. 2-4. Details are equipped with isothermal lines which define the structure condition in a stationary condition.

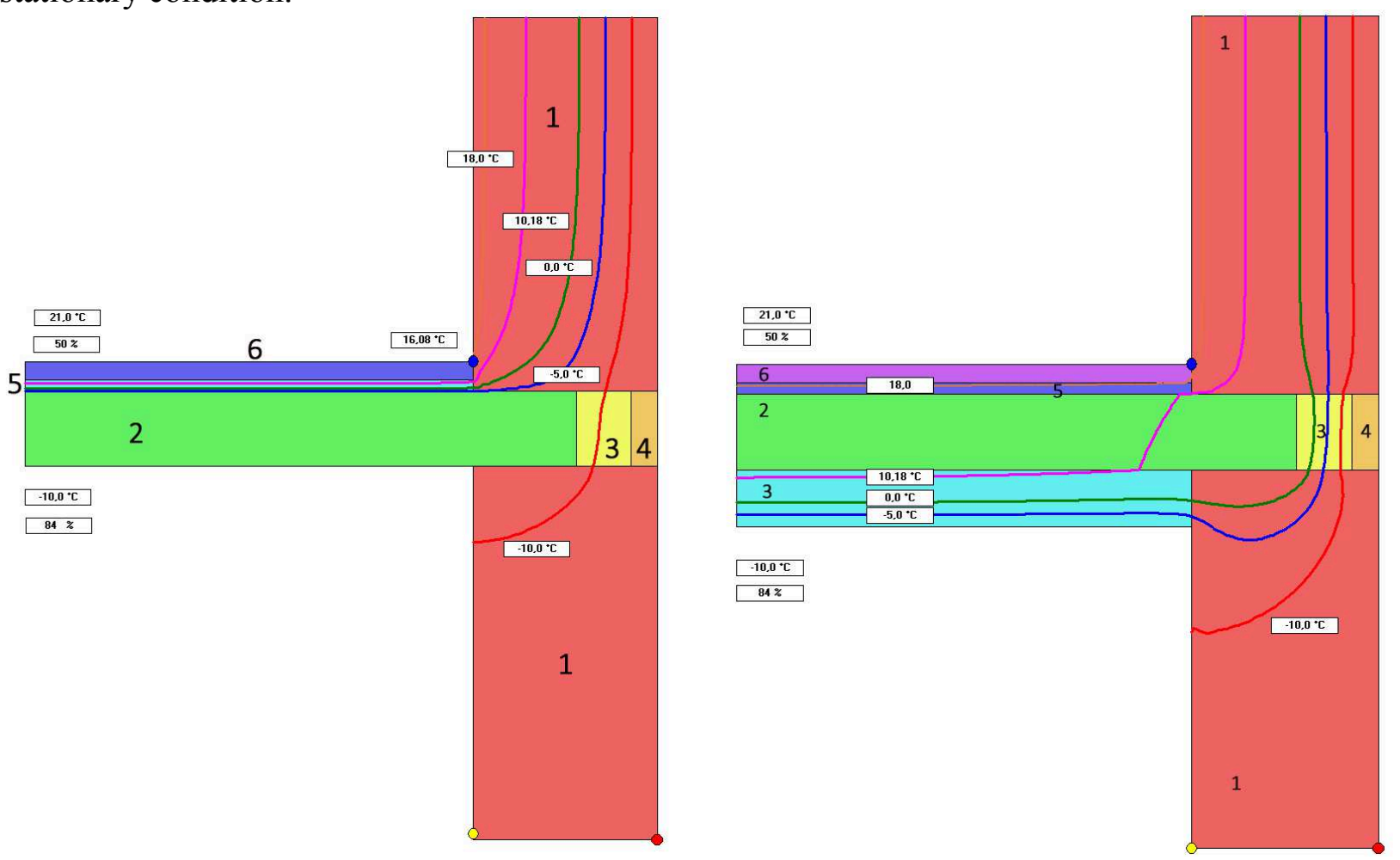

Fig. 2, Thermal fields of the ceiling and wall above the ventilated garage with a ceiling with no thermal insulation (left).

Fig. 3, Thermal fields of the ceiling and wall above the ventilated garage with a ceiling with thermal insulation (right).

Detail 1 has brick cladding with very good insulation capability. With thickness $500 \mathrm{~mm}$ it shows $U=0.17 \mathrm{~W} /\left(\mathrm{m}^{2} \cdot \mathrm{K}\right)$ The ceiling is reinforced concrete, $200 \mathrm{~mm}$ thick. The edge of the ceiling board is equipped with a thermal insulation agent of EPS, $150 \mathrm{~mm}$ wide. A $30 \mathrm{~mm}$ layer of sound insulation of fibre material is placed on the board. On this layer, there is a separation layer of polyethylene foil and a $50 \mathrm{~mm}$ distribution layer of simple concrete. Under the ceiling, the garage environment with natural ventilation with calculation temperature $\theta_{\mathrm{e}}=-10{ }^{\circ} \mathrm{C}$. Temperature difference $\Delta \theta=5 \mathrm{~K}$ considers the condition of the interior garage climate against the outside temperature. The calculation showed that in the critical spot, temperature in the place of contact of the horizontal and vertical structure reaches $\theta_{\mathrm{si}}=16.08{ }^{\circ} \mathrm{C}$, which is above dew point $\theta_{\mathrm{w}}=10.18{ }^{\circ} \mathrm{C}$, Fig. 2. In the garage, surface temperatures tend to be around $\theta_{\mathrm{si}}=-10^{\circ} \mathrm{C}$. This may cause a collision in intermediate periods. During these, in freezing days and in cases of sudden heat-up, ventilation may cause condensation of warm and moist air on cool surfaces in the garage

Detail 2 has a similar composition as Detail 1. Increased heat losses from the insufficiently $\lambda=0.038 \mathrm{~W} /(\mathrm{m} \cdot \mathrm{K})$, the lower face of the ceiling. In the critical spot of this Detail, this adjustment provided increase in interior temperature to $\theta_{\mathrm{si}}=18.84{ }^{\circ} \mathrm{C}$, Fig. 3.

Detail 3 consists in free placement of the parking spot under the building. The cladding is enclosed in thermal insulation in both the vertical and horizontal plane with $\lambda=0.038 \mathrm{~W} /(\mathrm{m} \cdot \mathrm{K})$, thickness $300 \mathrm{~mm}$. Here, the temperature is the highest in the critical spot and reaches $\theta_{\mathrm{si}}=18.90$ ${ }^{\circ} \mathrm{C}$, Fig. 4. 


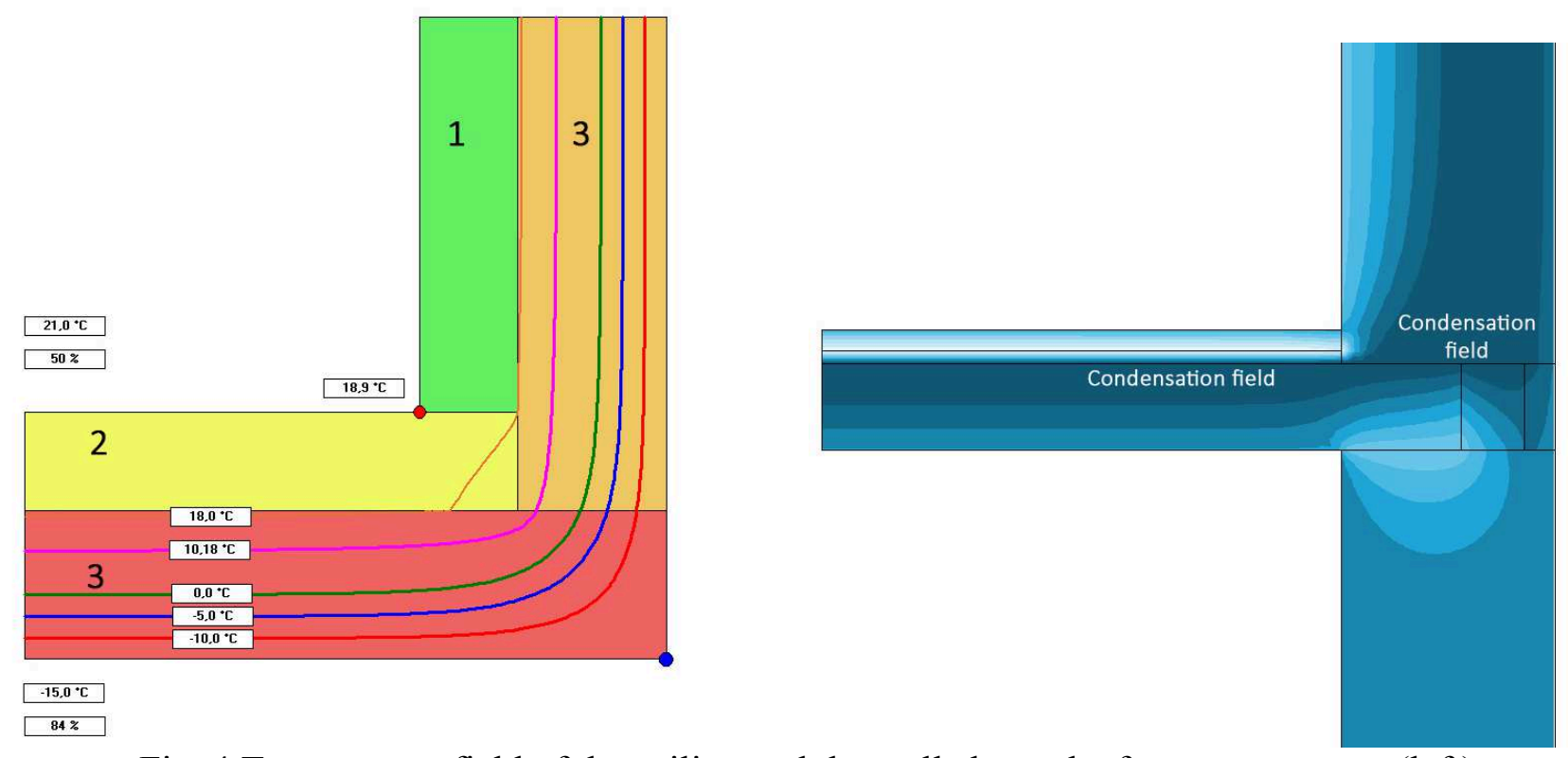

Fig. 4 Temperature field of the ceiling and the wall above the free garage space (left). Fig. 5 Moisture field with a diagram of condensate occurrence from Detail 1 (right).

\section{Analysis Response in Architectural Practice}

This knowledge leads the architect to wonder and consider them when designing a building. We can encounter good results abroad. In new houses in Austria and Germany, the tendency to park personal vehicles under carports is prevailing. Fig. 6-9 show several examples from Gleisdorf, Styria (Austria).
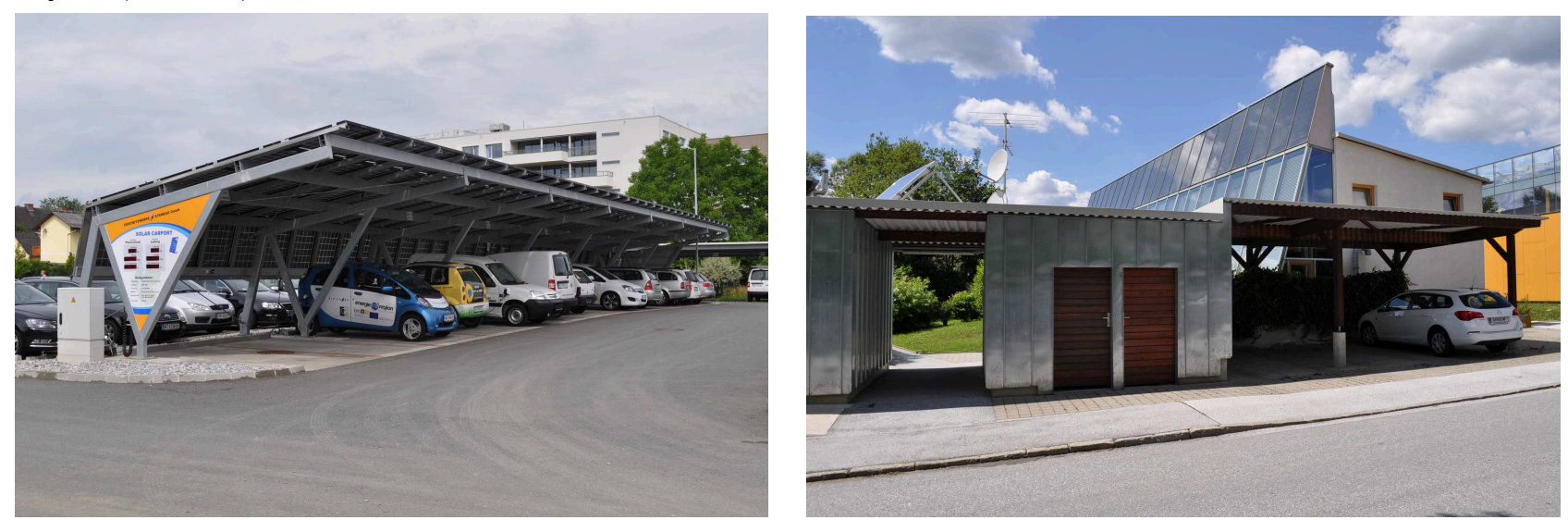

Fig. 6 Parking an electromobile under a carport with photovoltaic panels (left). Photo: J. Chybík. Fig. 7 A complex of houses with automobiles parked under a carport (right). Photo: J. Chybík
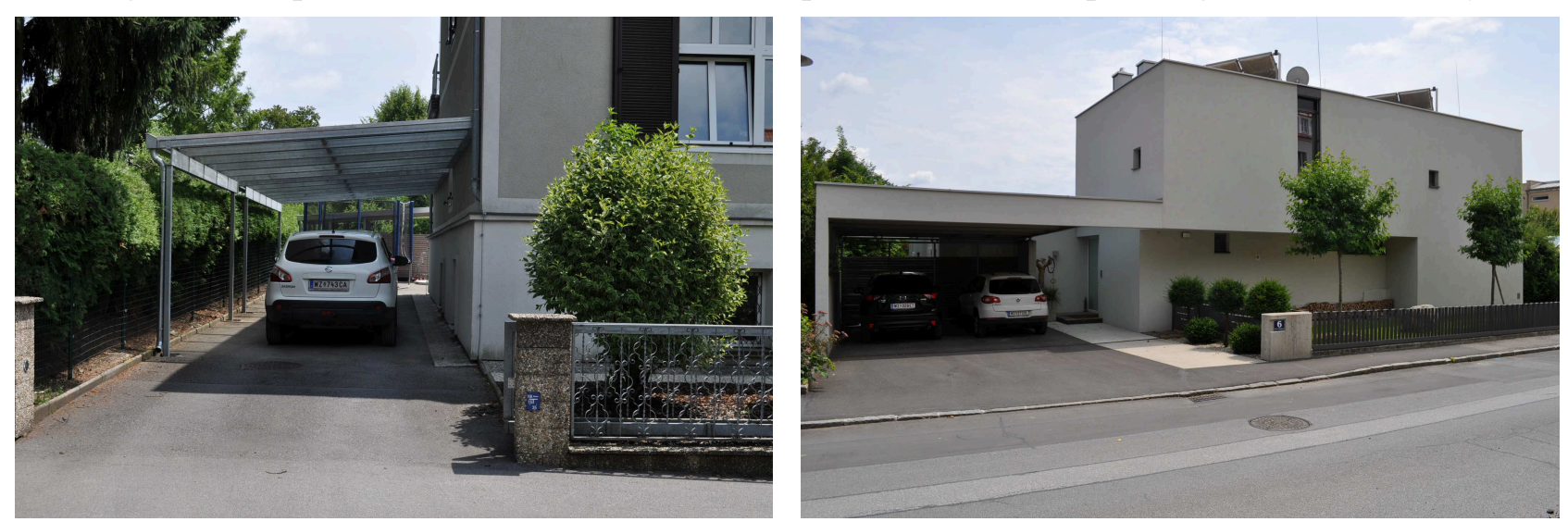

Fig. 8 A light carport made of metal and glass (left). Photo: J. Chybík.

Fig. 9 A carport by a residential building (right). Photo: J. Chybík. 


\section{Summary}

The analysis presented the issues of the contact of heated and unheated spaces. It used examples of garages designed within their inclusion into a residential building disposition. It has been proven that in terms of temperature and moisture, personal vehicles are best located under an unheated carport. Such location facilitates vehicle manipulation, prevents water vapour condensation on the top of car body and chassis. It eliminates undesirable energetic and temperature-moisture phenomena which manifest in increased demand on building heating.

The carport also reduces heat emitting from the car body. In the cool of the night, condensing is prevented on car body and glassed surfaces. In extreme weather conditions, vehicles are also protected against hailstorms. In winter, vehicles are spared frosting and effect of snow layers.

\section{References}

[1] CSN 73 0540-2 Thermal protection of buildings - Part 2: Requirements. UNMZ, 2011.

[2] CSN 736058 Single, multiple and collective garages. ÚNMZ, 2011.

[3] F. Drkal, Návrh větrání garáží (I). In TZB info, 2008, searched on 13.7.2014.

[4] F. Drkal, Návrh větrání garáží (II). In TZB info, 2008, searched on 13.7.2014.

[5] J. Chybík, Peripheral cladding with a deformed field of temperature. In: 11th International Scientific Conference, Brno, 1999, pp. 117-120.

[6] Z. Svoboda, Program AREA 2011.Information on http://www.weld.labs.gov.cn

[7] J. Štikar, Garáže, Brno, 2004, ERA group, 110 pgs. 